\title{
Personality characteristics of homosexual men suffering from sexually transmitted diseases
}

\author{
B. W. P. WELLS AND C. B. S. SCHOFIELD \\ From the Department of Psychology, Strathclyde University, and the Department of Venereology, Glasgow
}

This investigation is the most recent of a series of heuristic studies of patients attending special clinics for sexually transmitted diseases (Wells, 1968, 1969, 1970; Wells and Schofield, 1970). Apart from the general interest and value of building up a broad picture of the social and psychological characteristics of that vast body of patients, studies of certain groups, such as prostitutes and highly promiscuous women, have a special interest in terms of their epidemiological significance and problems of management.

The present study on male homosexuals contributes mainly to the former purpose. The particular interest of this group lies in the fact that from the psychiatric viewpoint they form a less selected sample than those who get into trouble with the police, are referred or volunteer for psychiatric treatment or, as is the more recent trend, are contactable through clubs and 'freedom' or 'liberation' groups. By contrast with these more readily accessible groups on whom most previous research has been focused, the attenders at special clinics tend to be 'adjusted' in the sense that they are now far less under the threat of persecution and are not seeking to be 'cured' of exhibiting their new-found freedom. In such circumstances, one might expect them to reflect the essential characteristics of homosexuality more truly than individuals subjected to the distorting pressures, both legal and social, which existed until quite recently.

Cattell and Morony (1962) used the Americandeveloped "16 Personality Factor Questionnaire" on two groups of Australian homosexuals-one group in prison after conviction for the offence, and the others located through social workers and by the 'infiltration' of homosexual cliques. They concluded that the members of the two groups were 'essentially the same species', and thus implied that their results were of relevance to both penal and therapeutic considerations of homosexuals. They found both groups to be more extroverted than neurotic patients, but 'much nearer to the various members of the clinical class of neurotics than to sociopaths, criminals,

Received for publication July 27,1971 psychopaths and psychosomatics'. However, Evans (1970), using the same technique on a group of self-confessed American homosexuals drawn from a larger group of volunteers for medical research who were not in legal difficulties and had never sought psychotherapy, produced different results and came to different conclusions. The score patterns differed from Cattell and Morony's in that the subjects, though slightly extroverted, were similar to the population mean, and the array of factors, which suggested to Cattell and Morony that their homosexuals might be regarded as neurotics presenting specific psychosexual symptoms, was rejected by Evans on the grounds that $(a)$ his own results did not support these findings and (b) 'it is questionable whether Cattell and Morony's own results justify them'. Evans concluded that 'American homosexuals as a group could be considered mildly neurotic at most, and that the results support the view that homosexual behaviour is not necessarily an indication of psychological disturbance. The main difference between the homosexuals and heterosexuals appeared to be one of sexual orientation rather than of psychopathology'.

Such conflicting findings regarding the characteristics of homosexuals are probably due to a number of variables but, among these, three stand out:

(1) Possible cross-cultural differences-due either to actual differences between current Australian and American culture-or to using tests standardized in one continent on subjects from another.

(2) Sample bias-as those homosexuals seen in prison or psychiatric clinics tend to differ either in level of intelligence or in the psychological conflicts which might make them seek psychiatric treatment.

(3) The notorious problem that persons volunteering as research subjects tend to be atypical of the groups they purport to represent (Rosnow and Rosenthal, 1970).

With these problems in mind, a study was undertaken using British subjects who were neither in legal 
difficulties nor seeking change, and who were not volunteers for research, and who were tested with an instrument standardized in Great Britain. The instrument chosen, the Eysenck Personality Inventory (EPI), having already been used in the same clinic to yield information about heterosexual patients (Wells, 1969), provided a useful baseline for making comparisons with the accrued data.

\section{Method}

One of us (CBSS), visits, during the course of each week, a number of special clinics in the Glasgow area. At these clinic sessions, each homosexual presenting himself for treatment was administered the Eysenck Personality Inventory, a personality measure of the self-completing type. Every identified homosexual was included until a sufficiently large group had been assembled; no refusals to participate were recorded. The patients were classified as 'active' or 'passive' homosexual, according to the type of sexual contact which had led them to seek treatment, although most of them stated that they also took part in other forms of homosexual behaviour.

The only additional information recorded for each individual was age, occupation, and marital status. In all, 109 cases were collected, but as the scale contains a device for detecting those people who appear to be manipulating their responses in order to appear more socially desirable, those who exceeded the lie-scale criterion of five or more points had to be excluded. This screening brought the size of the group remaining for analysis down to 91 .

\section{Results}

Only nine of the group were, or had been, married and, although they proved to be significantly older, there was no significant difference between the personality characteristics of the married and the single men. The patients came from all the social strata although there was an under-representation of unskilled manual workers.

Table I shows that the 'active-passive' classification failed to reveal any significant differences between groups in terms of age or of neuroticism and extroversion scores.

Table II summarizes a comparison between the results obtained in the present study and those based on a previous study (Wells, 1969) in which heterosexual 'special clinic' patients were the subjects.

The homosexual patients, as a group, proved to be significantly less extrovert than heterosexuals.

The next statistical test was for differences between the personality scores of the standardization sample of males used in preparing the test norms (Eysenck and Eysenck, 1964) and the present homosexual group (Table III). A test for age comparability was also included, as this variable is known to affect extroversion scores, but no significant difference emerged.

It was found that the homosexuals were very significantly more neurotic than the normal popula-

TABLE I Comparison of age, neuroticism, and extroversion scores for 'active' and 'passive' groups

\begin{tabular}{|c|c|c|c|c|c|c|c|c|}
\hline \multirow{2}{*}{\multicolumn{2}{|c|}{ Type of Homosexual }} & \multicolumn{3}{|l|}{ 'Active' } & \multicolumn{3}{|l|}{ 'Passive' } & \multirow[t]{2}{*}{ Significance of difference } \\
\hline & & Number of cases & Mean & S.D. & Number of cases & Mean & S.D. & \\
\hline \multicolumn{2}{|c|}{ Age (yrs) } & 41 & $26 \cdot 56$ & 10.07 & 50 & $26 \cdot 26$ & $9 \cdot 43$ & Not significant \\
\hline Score & $\begin{array}{l}\text { Neuroticism } \\
\text { Extroversion }\end{array}$ & $\begin{array}{l}41 \\
41\end{array}$ & $\begin{array}{l}12 \cdot 71 \\
11 \cdot 93\end{array}$ & $\begin{array}{l}5 \cdot 65 \\
3 \cdot 46\end{array}$ & $\begin{array}{l}50 \\
50\end{array}$ & $\begin{array}{l}13 \cdot 88 \\
12 \cdot 12\end{array}$ & $\begin{array}{l}5 \cdot 57 \\
3 \cdot 26\end{array}$ & $\begin{array}{l}\text { Not significant } \\
\text { Not significant }\end{array}$ \\
\hline
\end{tabular}

TABLE II Comparison of neuroticism and extroversion scores with those previously derived ${ }^{\star}$ for heterosexual patients

\begin{tabular}{|c|c|c|c|c|c|c|c|c|}
\hline \multirow[t]{2}{*}{ Group } & & \multicolumn{3}{|l|}{ Heterosexuals $\star$} & \multicolumn{3}{|l|}{ Homosexuals } & \multirow[t]{2}{*}{ Significance of difference } \\
\hline & & Number of cases & Mean & S.D. & Number of cases & Mean & S.D. & \\
\hline Score & $\begin{array}{l}\text { Neuroticism } \\
\text { Extroversion }\end{array}$ & $\begin{array}{l}50 \\
50\end{array}$ & $\begin{array}{l}11 \cdot 82 \\
13 \cdot 46\end{array}$ & $\begin{array}{l}4 \cdot 06 \\
3 \cdot 65\end{array}$ & $\begin{array}{l}91 \\
91\end{array}$ & $\begin{array}{l}13.35 \\
12 \cdot 03\end{array}$ & $\begin{array}{l}5 \cdot 60 \\
3 \cdot 34\end{array}$ & $\begin{array}{l}\text { Not significant } \\
P<0.05\end{array}$ \\
\hline
\end{tabular}

*Wells (1969)

TABLE III Comparison of age, and neuroticism and extroversion scores with test standardization group

\begin{tabular}{|c|c|c|c|c|c|c|c|c|}
\hline \multicolumn{2}{|l|}{ Group } & Number of cases & Mean & S.D. & Number of cases & Mean & S.D. & Significance of difference \\
\hline Score & $\begin{array}{l}\text { Neuroticism } \\
\text { Extroversion }\end{array}$ & $\begin{array}{l}91 \\
91\end{array}$ & $\begin{array}{l}13 \cdot 35 \\
12 \cdot 03\end{array}$ & $\begin{array}{l}5.60 \\
3.34\end{array}$ & $\begin{array}{l}2,000 \\
2,000\end{array}$ & $\begin{array}{r}9 \cdot 07 \\
12 \cdot 07\end{array}$ & $\begin{array}{l}4 \cdot 78 \\
4 \cdot 37\end{array}$ & $\begin{array}{l}\mathrm{P}<<0.001 \\
\text { Not significant }\end{array}$ \\
\hline
\end{tabular}


tion: a finding previously reported for the heterosexual patients tested on the same inventory (Wells, 1969).

Finally, comparisons were made between 'active' and 'passive' homosexuals on the one hand and male and female heterosexual clinic patients on the other. There was no significant difference in neuroticism or extroversion between the 'active' homosexuals and the male or female heterosexuals nor between 'passive' homosexuals and female heterosexuals, but there was a difference in neuroticism between 'passive' homosexuals and male heterosexuals (Table IV).

The Figure shows more clearly the relative status of homosexuals on the neuroticism and extroversion parameters when compared with the data for the normal population and for a range of clinically neurotic patients (Eysenck and Eysenck, 1964). Also included are the data for male and female heterosexual patients reported in the previous study (Wells, 1969).

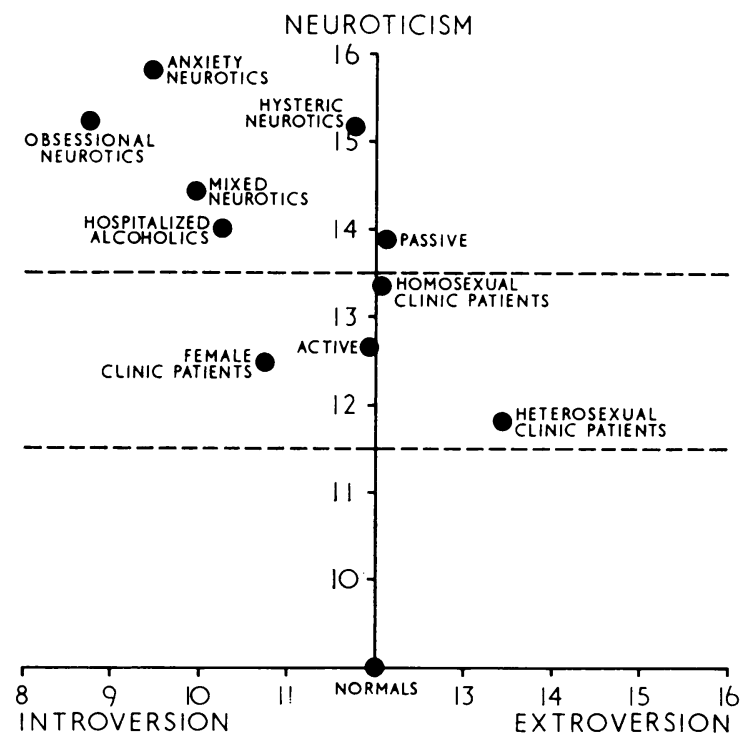

FIGURE Comparison of homosexual men and heterosexual special clinic patients with the normal population and clinical neurotics

\section{Discussion}

The findings appear to be fairly clear-cut: the homosexuals are distinguishable from heterosexual male patients in that they are certainly less extroverted and are somewhat more neurotic. 'Passive' male homosexuals were significantly more neurotic than heterosexual male patients.

The results are of some interest in that they serve to demonstrate once again, though in a different sub-group, that patients attending special clinics show a clear tendency to emotional instability. This supports the findings of Pedder and Goldberg (1970), who found that approximately 30 per cent. of all new admissions to a special clinic were 'probable' psychiatric cases on the basis of Goldberg's own General Health Questionnaire (GHQ) and suggested that investigation and referral facilities were therefore desirable. Nevertheless, they found that homosexuals had low scores for psychiatric disturbances, and from a more recent study (Pedder, 1970) it was concluded that many homosexual patients, having a low motivation to change their homosexual activities, were free from overt emotional disturbance. But in view of the very small numbers involved in Pedder's study (12) and because two of these patients were currently suffering from acute anxiety states, one would have had more confidence in findings based on such well-established and widely validated scales as the EPI.

In view of the general agreement between Pedder and Goldberg and ourselves that emotional disturbances are more prevalent among patients with sexually transmitted diseases, one might profitably look for the reasons behind any differences when more data on the GHQ are available.

In effect, Pedder and Goldberg (1970) seemed to exclude homosexuals from the class of reactive neurotic patients and to regard them more as adjusted but differently orientated individuals.

The present study is not able to deal with the question whether the differences found in homosexuals are inborn and are founded upon physiological or anatomical substrates. Supporters of this view are heirs to a venerable tradition, expressed trenchantly by such research workers as Hirschfeld (1946) though countered by the work of Henry (1941) and Cory

TABLE IV Comparison of neuroticism and extroversion scores between heterosexuals and passive homosexuals

\begin{tabular}{|c|c|c|c|c|c|c|c|c|}
\hline \multirow{2}{*}{\multicolumn{2}{|c|}{ Group }} & \multicolumn{3}{|l|}{ Heterosexuals } & \multicolumn{3}{|c|}{ Passive homosexuals } & \multirow[t]{2}{*}{ Significance of difference } \\
\hline & & Number of cases & Mean & S.D. & Number of cases & Mean & S.D. & \\
\hline Score & $\begin{array}{l}\text { Neuroticism } \\
\text { Extroversion }\end{array}$ & $\begin{array}{l}50 \\
50\end{array}$ & $\begin{array}{l}11 \cdot 82 \\
13 \cdot 46\end{array}$ & $\begin{array}{l}4 \cdot 06 \\
3 \cdot 65\end{array}$ & $\begin{array}{l}50 \\
50\end{array}$ & $\begin{array}{l}13 \cdot 88 \\
12 \cdot 12\end{array}$ & $\begin{array}{l}5 \cdot 57 \\
3 \cdot 34\end{array}$ & $\begin{array}{l}P<0.05 \\
\text { Not significant }\end{array}$ \\
\hline
\end{tabular}


(1956). However, in view of Eysenck's own conclusions that the Neuroticism Factor measures genetically transmitted qualities of autonomic functioning (Eysenck and Eysenck, 1964), the present findings may prove to be of some interest in a more broadly based evaluation.

The classification of homosexual patients into 'active' and 'passive' is accepted as being somewhat artificial and arbitrary, and it is known that the roles often vary depending upon the interactions of personality and that many homosexuals habitually take both roles. The classification was seen as no more than a tentative strategy concerned mainly with checking whether the 'active'- 'passive' dichotomy, based on clinical signs and symptoms, is a realistic concept. The study produced no evidence that this is so, though from an epidemiological point of view, the matter would merit further study.

\section{Summary}

The Eysenck Personality Inventory was administered to 109 homosexual men successively presenting for treatment at special clinics for sexually transmitted diseases. It was found that the 'active'-'passive' classification based on clinical signs and symptoms yielded no distinguishable groups; homosexuals as a group scored lower for extroversion than heterosexual males but, like them, were significantly more neurotic than the general population.

\section{References}

Cattell, R. B., and MORONY, J. H. (1962) F. consult. Psychol., 26, 531

CoRY, D. W. (1956) 'Homosexuality: A Cross-Cultural Approach'. Julian Press, New York
Evans, R. B. (1970) f. consult. clin. Psychol., 34, 212

EYSENCK, H. J., and EysENCK, S. B. G. (1964) 'Manual of the Eysenck Personality Inventory'. University of London Press

HeNRY, G. W. (1941) 'Sex Variants: A Study of Homosexual Patterns'. Hoeber, New York

HiRsChfeld, M. (1946) 'Sexual Anomalies and Perversions: Physical and Psychological Development and Treatment'. Torch, London

Pedder, J. R. (1970). Brit. F. vener. Dis., 46, 54

— and GolDBERG, D. P. (1970) Ibid., 46, 58

Rosnow, R. L., and Rosenthal, R. (1970). 'Volunteer Effects in Behavioral Research', in 'New Directions in Psychology', 4, p. 211. Holt, Rinehart, and Winston, New York

Wells, B. W. P. (1968) Biol and hum. Affairs, 33, 26

- (1969) Brit. F. soc. clin. Psychol., 8, 246

- (1970) Brit. F. vener. Dis., 46, 498

- and SchofikLd, C. B. S. (1970) Health Bull. (Edinb.), 28, no. 1 , p. 75

\section{Caractéristiques de la personnalité chez des malades homosexuels atteints de maladies transmises sexuellement}

\section{SOMMAIRE}

Le bilan de personnalité Eysenck fut établi dans une série consecutive de 109 homosexuels masculins se présentant pour traitement dans les cliniques spécialisées en vénéréologie. On a trouvé que la distinction entre 'actifs''passifs', telle qu'on peut la fonder sur les signes et les symptômes cliniques, ne conduit pas à un classement en groupes distincts; les homosexuels en tant que groupe s'inscrivent, en ce qui concerne l'extroversion, audessous des hétérosexuels masculins mais, comme eux et d'une manière significative, se présentent comme plus névrotiques que la population générale. 